\title{
Pengaruh Model Pembelajaran Inkuiri Dengan Dan Kemampuan Berpikir Logis Terhadap Hasil Belajar Siswa Pada Materi Laju Reaksi
}

\section{The Effect of Inquiry Learning Method by Using Laboratory and Logical Thinking on Learning Outcome in Chemical Reaction Rate}

\author{
Gulmah Sugiharti* dan Siti Kholilah Hasibuan* \\ Jurusan Kimia, Fakultas MIPA, Universitas Negeri Medan, Medan-Indonesia \\ *Korespondensi: gulmahsugiharti@yahoo.com; kholilahhsb6@gmail.com
}

\begin{abstract}
Abstrak: Penelitian ini bertujuan untuk mengetahui pengaruh model pembelajaran dengan menggunakan laboratorium dan kemampuan berpikir logis terhadap hasil belajar kimia siswa pada materi laju reaksi. Penelitian dilakukan terhadap siswa kelas XI IPA MAN 2 Model Medan T. A. 2016/2017. Populasi dalam penelitian ini adalah seluruh siswa kelas XI IPA MAN 2 Model Medan yang terdiri dari 8 kelas. Sampel ditetapkan dengan purposive sampling yakni mengambil 2 kelas yang dijadikan kelas eksperimen. Jenis penelitian ini adalah jenis ekperimen dengan rancangan factorial $2 \times 2$. Pengambilan data untuk hasil belajar siswa diperoleh dengan tes hasil belajar yang menggunakan instrumen yang valid sebanyak 23 soal dan reliabel $(0,875)$. Sedangkan, data untuk kemampuan berpikir logis siswa diperoleh melalui angket kemampuan berpikir logis dengan menggunakan data instrumen yang telah valid. Teknik analisa data menggunakan analisis varian dua jalur. Hasil penelitian menunjukkan terdapat pengaruh model pembelajaran inkuiri dengan menggunakan laboratorium riil dan laboratorium virtual terhadap hasil belajar kimia siswa pada materi laju reaksi dengan nilai $\mathrm{F}$ hitung > F tabel yaitu 28,6367> 3,99, terdapat pengaruh kemampuan berpikir logis tinggi dan kemampuan berpikir logis rendah terhadap hasil belajar kimia siswa pada materi laju reaksi dengan nilai $\mathrm{F}$ hitung $>\mathrm{F}$ tabel yaitu 21,6251>3,99, dan terdapat interaksi antara model pembelajaran dengan kemampuan berpikir logis terhadap hasil belajar kimia siswa pada materi laju reaksi dengan nilai F hitung > F tabel yaitu 20,7645> 3,99.
\end{abstract}

Kata kunci: hasil belajar, interaksi, laboratorium virtual, laboratorium real, model pembelajaran inkuiri

\begin{abstract}
This research aims to discover the effect of learning models using laboratory and logical thinking ability to the students of chemistry learning outcomes on the material rate of the reaction. The research was conducted on the students of class XI IPA MAN 2 Model Medan T. A. 2016/2017. The population in this research is all students of class XI IPA MAN 2 Model Medan which consists of 8 classes. The sample is determined by purposive sampling that takes 2 classes that made the experimental class. This type of research is experimental type with factorial design $2 x$ 2. Data retrieval for student learning outcomes obtained by test of learning result using valid instrument as much as 23 questions and reliable $(0,875)$. Whereas, the data for students logical thinking ability is obtained through questionnaire of logical thinking ability by using valid instrument data. Data analysis techniques used two-way variance analysis. The result of research shows that there is influence of Inquiry learning model by using real laboratory and virtual laboratory on students' chemistry learning result on reaction rate material with Fcount> Ftable that is 28,6367> 3,99, there is influence of high logical thinking ability and low logical thinking ability to the result of student's chemistry learning on the material of reaction rate with Fcount> Ftable is 21,6251> 3,99, and there is interaction between learning model with logical thinking ability to student's chemistry learning on reaction rate material with Fcount $>$ Ftable that is $20,7645>3.99$.
\end{abstract}

Keywords: learning outcomes, interaction, virtual laboratory, real laboratory, inquiry learning model

\section{PENDAHULUAN}

Masalah utama dalam pembelajaran pada pendidikan (sekolah) adalah masih rendahnya daya serap peserta didik. Hal ini tampak dari rerata hasil belajar peserta didik yang senantiasa masih sangat memprihatinkan. Prestasi ini tentunya merupakan hasil kondisi pembelajaran yang masih bersifat konvensional dan tidak menyentuh ranah dimensi peserta didik itu sendiri. Dalam arti yang lebih substansial, bahwa proses pembelajaran hingga saat ini masih memberikan dominasi guru dan tidak memberikan akses bagi anak didik untuk berkembang secara mandiri melalui proses berpikirnya. Menurut Trianto (2014), untuk mencapai tujuan pendidikan nasional, pemerintah telah menyelenggarakan perbaikan-perbaikan peningkatan mutu pendidikan pada berbagai jenis dan jenjang. Namun fakta belum menunjukkan hasil yang memuaskan.

Keberhasilan suatu pembelajaran dapat dilihat dari kemampuan belajar peserta didik 
secara mandiri, sehingga pengetahuan yang dikuasai adalah hasil belajar yang dilakukannya sendiri. Oleh karena itu, pendekatan yang digunakan dalam proses pembelajaran hendaknya menciptakan dan menumbuhkan rasa dari tidak tahu menjadi mau tahu, sehingga kurikulum 2013 mengamatkan esensi pendekatan ilmiah untuk digunakan dalam proses pembelajaran. Hasil observasi di Madrasah Aliyah Negeri (MAN) 2 Model Medan yang menerapkan kurikulum 2013 dalam proses belajar mengajarnya, menetapkan Kriteria Ketuntasan Minimal (KKM) untuk pelajaran kimia yaitu 75,00. Siswa dengan nilai $\geq 75$, oo dinyatakan tuntas dan siswa dengan nilai $<75$, oo dinyatakan belum tuntas, sehingga perlu mengikuti remedial. Hasil belajar itu tergolong masih rendah karena kurangnya perhatian siswa saat proses pembelajaran berlangsung dan langkah-langkah dari model pembelajaran yang masih berorientasi pada guru, sehingga mengakibatkan siswa cenderung tidak tertarik untuk belajar. Hal ini mengakibatkan masih banyak dari siswa yang belum mencapai nilai kriteria ketuntasan makimum (KKM) pada mata pelajaran kimia, termasuk materi pokok laju reaksi.

Materi pokok laju reaksi ini berisikan tentang teori tumbukan yaitu menjelaskan reaksi kimia, sedangkan untuk faktor-faktor yang mempengaruhi laju reaksi karakteristik materinya adalah aplikasi dalam kehidupan sehari-hari, karena bersifat aplikasi, maka seharusnya diajarkan dengan metode eksperimen. Dengan melakukan eksperimen langsung di laboratorium siswa dapat mengamati secara langsung perubahanperubahan yang terjadi, yang pada akhirnya dapat memahamkan sendiri konsep yang akan dipelajarinya, sehingga pembelajaran yang terjadi lebih bermanfaat bagi siswa.

Selain itu, pada materi laju reaksi diperlukan tahapan analisis pada beberapa bagiannya terutama pada hubungan antara teori tumbukan dan faktor- faktor yang mempengaruhinya, sehingga laju reaksi dapat digunakan sebagai media untuk mengembangkan kemampuan berpiki logis. Hal ini sejalan dengan Permendiknas No.23 Tahun 2006 mengenai standar kelulusan SMA bahwa siswa SMA harus memiliki kemampuan berpikir logis, kritis, kreatif dan inovatif dalam pengambilan keputusan. Untuk memberikan kemampuan berpikir logis, siswa tidak diajarkan secara khusus sebagai satu mata pelajaran tetapi melalui setiap mata pelajaran aspek berpikir logis mendapatkan tempat yang utama (Fatturohman, 2015) artinya setiap kegiatan pembelajaran dapat menggali kemampuan berpikir logis siswa terutama pada topik laju reaksi yang memuat banyak konsep abstrak dan perhitungan,

Kemampuan berpikir logis merupakan salah satu kemampuan berpikir yang harus dimiliki oleh siswa. Kemampuan berpikir logis biasa dikenal juga dengan kemampuan menalar. Menurut Suriasumantri (2015) kemampuan berpikir logis (penalaran) yaitu kemampuan menemukan suatu kebenaran berdasarkan aturan, pola, atau logika tertentu. Oleh karena itu, berdasarkan kemampuan berpikir logis yang dimiliki oleh siswa maka seorang guru harus mampu memilih dan menggunakan model pembelajaran yang sesuai dengan karakteristik siswa tersebut, termasuk model pembelajaran inkuiri.

Model pembelajaran inkuiri merupakan pembelajaran dengan seni merekayasa situasisituasi yang sedemikian rupa sehingga siswa bisa berperan sebagai ilmuwan. Siswa diajak untuk bisa memiliki inisiatif untuk mengamati dan menayangkan gejala alam, mengajukan penjelasan-penjelasan tentang apa yang mereka lihat, merancang dan melakukan pengujian untuk menunjang atau menentang teori-teori mereka, menganalisis data, menarik kesimpulan dari data eksperimen, merancang dan membangun model. Model pembelajaran inkuiri akan lebih efektif jika dipadukan dengan penggunaan laboratorium yaitu menggunakan laboratorium real dan laboratorium virtual dengan menggunakan komputer (animasi).

Laboratorium virtual adalah laboratorium dalam layar yang berisi animasi praktikum menyerupai praktikum dalam laboratorium nyata (Nurrokhmah dan Sunarto 2013). Menurut Swandi dkk. (2014) laboratorium virtual merupakan bentuk animasi yang dapat memvisualisasikan fenomena yang abstrak atau percobaan yang rumit dilakukan di laboratorium nyata, sehingga dapat meningkatkan aktivitas belajar dalam upaya mengembangkan keterampilan yang dibutuhkan dalam pemecahan masalah. Laboratorium virtual merupakan salah satu bentuk dari animasi komputer, berupa gambar bergerak yang merupakan representatif keadaan di laboratorium riil. 
Laboratorium riil menggunakan peralatan dan bahan-bahan laboratorium yang nyata. Laboratorium riil adalah tempat berupa ruangan yang dilengkapi dengan berbagai peralatan. Alat, bahan, dan obyek pengamatan yang ada di laboratorium adalah fasilitas yang berfungsi untuk kegiatan percobaan dan penelitian bagi siswa (Gahardiana, 2015). Peneliti ingin mengkomparasikan laboratorium riil dan laboratorium virtual yang digunakan dalam pembelajaran Inkuiri pada materi laju reaksi yang diharapkan menjadi alternatif pembelajaran yang mampu mempengaruhi kemampuan berpikir logis siswa.

Beberapa penelitian yang berhubungan antara lain Hamida dkk. (2012) menemukan adanya pengaruh penggunaan laboratorium virtual dan laboratorium real terhadap prestasi belajar siswa, dan penggunaan laboratorium virtual memperoleh nilai ratarata lebih besar dari penggunaan laboratorium real. Sedangkan penelitian Argandi dkk. (2013) menyimpulkan terdapat perbedaan prestasi hasil belajar siswa yang diajar dengan menggunakan laboratorium real pada pembelajaran inkuiri, demikian pula aspek afektifnya. Selanjutnya dikatakan pembelajarn kimia dengan metode inkuiri menggunakan real lab (80,95\%) lebih tinggi dari pada pembelajaran inkuiri menggunakan virtual lab (74,40\%). Penelitian Pratiwi (2016) menyimpulkan pembelajaran inkuiri memberikan sumbangan sebesar 28,23\% terhadap peningkatan hasil belajar siswa.

Penelitian ini bertujuan untuk mengetahui apakah ada pengaruh model pembelajaran inkuiri dengan menggunakan laboratorium riil dan laboratorium virtual terhadap hasil belajar siswa, apakah ada pengaruh kemampuan berpikir logis tinggi dan kemampuan berpikir logis rendah terhadap hasil belajar siswa dan apakah ada interaksi antara model pembelajaran dengan kemampuan berpikir logis terhadap hasil belajar siswa pada materi laju reaksi.

\section{METODE}

Penelitian ini dilaksanakan di sekolah MAN 2 model Medan kelas XI semester ganjil tahun ajaran 2016/2017 sejak bulan September sampai Oktober tahun 2016. Rancangan penelitian yang digunakan adalah rancangan faktrorial $2 \times 2$. Ada dua faktor yang diteliti yaitu faktor model pembelajaran inkuiri dengan menggunakan laboratorium (A) dan faktor kemampuan berpikir logis (B). Faktor A ada dua taraf yaitu model pembelajaran dengan menggunakan laboratorium riil dan laboratorium virtual. Untuk faktor B ada dua taraf yaitu kemampuan berpikir logis tinggi dan rendah. Secara rinci rancangan penelitian ini ditunjukkan pada Tabel 1.

Tabel 1. Rancangan penelitian Faktorial 2 x 2

\begin{tabular}{lll}
\hline Kemampuan & \multicolumn{2}{c}{ Model Inkuiri $(\mathrm{A})$} \\
\cline { 2 - 3 } Berpikir Logis & $\begin{array}{l}\text { Model Inkuiri dengan } \\
\text { menggunakan }\end{array}$ & $\begin{array}{l}\text { Model Inkuiri dengan } \\
\text { menggunakan laboratorium }\end{array}$ \\
& laboratorium Riil $\left(\mathrm{A}_{1}\right)$ & Virtual $\left(\mathrm{A}_{2}\right)$ \\
\hline Tinggi $\left(\mathrm{B}_{1}\right)$ & $\mathrm{A}_{1} \mathrm{~B}_{1}$ & $\mathrm{~A}_{2} \mathrm{~B}_{1}$ \\
Rendah $\left(\mathrm{B}_{2}\right)$ & $\mathrm{A}_{1} \mathrm{~B}_{2}$ & $\mathrm{~A}_{2} \mathrm{~B}_{2}$ \\
\hline
\end{tabular}

$\mathrm{A}_{1} \mathrm{~B}_{1}=\quad$ Kombinasi perlakuan Model Inkuiri dengan menggunakan laboratorium Riil dan kemampuan berpikir logis tinggi.

$\mathrm{A}_{1} \mathrm{~B}_{2}=$ Kombinasi perlakuan Model Inkuiri dengan menggunakan laboratorium Riil dan kemampuan berpikir logis rendah.

$\mathrm{A}_{2} \mathrm{~B}_{1}=$ Kombinasi perlakuan Model Inkuiri dengan menggunakan laboratorium Virtual dan kemampuan berpikir logis tinggi.

$\mathrm{A}_{2} \mathrm{~B}_{2}=$ Kombinasi perlakuan Model Inkuiri dengan menggunakan laboratorium Virtual dan kemampuan berpikir logis rendah.

Instrumen penelitian berupa kuesioner (angket) kemampuan berpikir logis yang dikembangkan berdasarkan indikatorindikator kemampuan berpikir logis pada bagian kerangka teoritis. Analisa datanya dilakukan dengan memberikan penilaian pada setiap siswa kemudian dicari rata-ratanya, siswa yang memperoleh nilai diatas rata-rata dikelompokkan sebagai siswa yang memiliki kemampuan berpikir logis tinggi dan siswa yang memperoleh nilai dibawah rata-rata dikelompokkan sebagai siswa yang memiliki kemampuan berpikir logis rendah. 


\section{HASIL DAN PEMBAHASAN}

Data yang terkumpul pada penelitian ini meliputi: data angket kemampuan berpikir logis dan hasil belajar kimia siswa. Data angket kemampuan berpikir logis ini dikelompokkan dalam 2 kategori yaitu kemampuan berpikir logis tinggi bagi siswa yang mempunyai nilai kemampuan berpikir logis $\geq$ rata-rata nilai kemampuan berpikir logis seluruh siswa. Kategori berpikir logis rendah bagi siswa yang mempunyai nilai kemampuan berpikir logis s rata-rata nilai kemampuan berpikir logis seluruh siswa. Secara keseluruhan data kemampuan berpikir logis tinggi dan rendah ditunjukkan pada Tabel 2.

Data hasil belajar kimia siswa dalam penelitian ini diperoleh dari tes hasil belajar. Untuk siswa yang diajar dengan model pembelajaran Inkuiri menggunakan laboratorium riil dengan kemampuan berpikir logis tinggi diperoleh rataan hasil belajar $(83,77 \pm 6,07)$, untuk kelas yang diajar dengan model pembelajaran Inkuiri menggunakan laboratorium riil kemampuan berpikir logis rendah diperoleh rataan hasil belajar
$(76,17 \pm 6,71)$. Sedangkan untuk kelas yang diajar dengan model pembelajaran Inkuiri menggunakan laboratorium virtual dengan kemampuan berpikir logis tinggi diperoleh rataan $(82 \pm 6,58)$, dan untuk kelas yang diajar dengan model pembelajaran Inkuiri menggunakan laboratorium virtual dengan kemampuan berpikir logis rendah diperoleh rataan $(76,29 \pm 7,84)$. Rincian rataan hasil belajar kimia yang diperoleh siswa untuk setiap kombinasi perlakuan ditunjukkan pada Tabel 3.

Pengujian hipotesis dilakukan dengan uji Analisis of Varians (ANAVA) pada $\alpha=0,05$ dengan kriteria jika $F_{\text {hitung }}>F_{\text {Tabel }}$ maka Ho ditolak. Berdasarkan perhitungan uji hipotesis data hasil belajar siswa, disimpulkan ada interaksi antara kemampuan berpikir logis (B) dengan model pembelajaran dengan menggunakan laboratorium (A) terhadap hasil belajar kimia siswa SMA. Daftar anava nilai siswa SMA yang diberi kombinasi perlakuan model pembelajaran menggunakan laboratorium dan kemampuan berpikir logis ditunjukkan pada Tabel 4 .

Tabel 2. Distribusi data kemampuan berpikir logis tinggi dan rendah

\begin{tabular}{|c|c|c|c|}
\hline \multirow[b]{2}{*}{ Kemampuan Berpikir logis } & \multirow{2}{*}{ Jumlah } & Kelas eksperimen 1 & Kelas eksperimen 2 \\
\hline & & \multicolumn{2}{|l|}{ Frekuensi } \\
\hline Tinggi & 35 & 18 & 17 \\
\hline Rendah & 33 & 16 & 17 \\
\hline Jumlah & 68 & 34 & 34 \\
\hline
\end{tabular}

Tabel 3. Rataan hasil belajar kimia siswa yang diberi kombinasi perlakuan model pembelajaran menggunakan laboratorium dan kemampuan berpikir logis.

\begin{tabular}{lll}
\hline \multirow{2}{*}{ Kemampuan Berpikir logis $(\mathrm{B})$} & \multicolumn{2}{l}{ Model Pembelajaran Dengan Menggunakan laboratorium $(\mathrm{A})$} \\
\cline { 2 - 3 } & $\begin{array}{l}\text { Model Inkuiri menggunakan } \\
\text { laboratorium riil }\left(\mathrm{A}_{1}\right)\end{array}$ & $\begin{array}{l}\text { Model Inkuiri menggunakan } \\
\text { laboratorium virtual }\left(\mathrm{A}_{2}\right)\end{array}$ \\
\hline Tinggi $\left(\mathrm{B}_{1}\right)$ & $(83,77 \pm 6,07)$ & $(82 \pm 6,58)$ \\
Rendah $\left(\mathrm{B}_{2}\right)$ & $(76,17 \pm 6,71)$, & $(76,29 \pm 7,84)$ \\
\hline
\end{tabular}

Tabel 4. Daftar anava nilai kimia siswa yang diberi kombinasi perlakuan model pembelajaran dengan menggunakan laboratorium dan kemampuan berpikir logis.

\begin{tabular}{llllll}
$\begin{array}{l}\text { Sumber } \\
\text { Keberagaman }\end{array}$ & Db & JK & KT & F hitung & $\mathrm{F}(\mathrm{o}, \mathrm{O} 5, \mathrm{db})$ \\
\hline Perlakuan & 3 & 1912,75 & - & - & - \\
Faktor A & 1 & 771,1911 & 771,1911 & 28,6367 & 3,99 \\
Faktor B & 1 & 582,3676 & 582,3676 & 21,6251 & 3,99 \\
Interaksi AB & 1 & 559,1913 & 559,1913 & $20,7645^{*}$ & 3,99 \\
Galat & 64 & 1723,529 & 26,9301 & & - \\
Total & 70 & 5549,0298 & - & - & - \\
\hline
\end{tabular}




\section{Hipotesis 1}

$\mathrm{F}_{\text {hitung }}(\mathrm{A})>\mathrm{F}_{(0,05)(1 ; 64)}$ dimana 28,63 > 3,99 maka $\mathrm{Ho}_{1}$ ditolak, ada pengaruh model pembelajaran inkuiri dengan menggunakan media riil dan media virtual terhadap hasil belajar siswa pada materi laju reaksi. Model pembelajaran yang digunakan dalam penelitian ini adalah model pembelajaran Inkuiri menggunakan laboratorium riil dan model pembelajaran Inkuiri menggunakan laboratorium virtual. Pengaruh tersebut menunjukkan bahwa kelas yang dibelajarkan dengan model pembelajaran inkuiri dengan menggunakan laboratorium riil memiliki skor rata-rata hasil belajar lebih tinggi yaitu 82,9705 dibanding model pembelajaran inkuiri dengan menggunakan laboratorium virtual yaitu 76,2352. Hasil penelitian Rohmawati dkk. (2016), menemukan besarnya rataan prestasi belajar kognitif siswa yang diajar dengan menggunakan laboratorium riil adalah 80,33. Besarnya rataan prestasi siswa yang diajar dengan menggunakan laboratorium virtual adalah 80,22. Hal tersebut menunjukkan bahwa pembelajaran dengan model inkuiri dengan menggunakan laboratorium riil lebih baik daripada menggunakan laboratorium virtual. Tetapi penelitian Rokhimullah (2010) menyimpulkan adanya pengaruh penggunaan laboratorium virtual dan laboratorium riil terhadap hasil belajar siswa dimana nilai ratarata penggunaan laboratorium virtual 61,24 dan nilai rata-rata penggunaan laboratorium real 53,52 .

\section{Hipotesis 2}

$\mathrm{F}_{\text {hitung }}(\mathrm{B})>\mathrm{F}_{(0,05)(1 ; 64)}$ dimana 21,62 > 3,99 maka $\mathrm{Ho}_{2}$ ditolak, maka ada pengaruh kemampuan berpikir logis tinggi dan kemampuan berpikir logis rendah terhadap hasil belajar siswa pada materi laju reaksi. Data hasil belajar siswa pada materi laju reaksi disimpulkan bahwa siswa yang memiliki kemampuan berpikir logis tinggi memberikan rataan hasil belajar yang lebih tinggi dibandingkan dengan siswa yang memiliki kemampuan berpikir logis rendah. Hal ini sejalan dengan penelitian yang dilakukan Legimin (2010) yang menyatakan bahwa terdapat pengaruh kemampuan berpikir logis tinggi dan kemampuan berpikir logis rendah terhadap prestasi belajar siswa. Kemampuan berpikir logis tinggi akan lebih mudah/merespon pelajaran dan tidak akan mengalami kesulitan yang berarti untuk belajar sedangkan untuk siswa yang memiliki kemampuan berpikir logis rendah akan mengalami kesulitan karena dia tidak memahami ketentuan-ketentuan, kaidahkaidah dan teknik berpikir yang tepat.

Made Ardana meneliti tentang kontribusi bakat numerik, kecerdasan spasial dan kecerdasan logis terhadap prestasi belajar menjelaskan bahwa kecerdasan logis memberikan kontribusi yang signifikan terhadap hasil belajar. Selanjutnya Wulansari meneliti tentang pengaruh kecerdasan logis matematis, terhadap pemahaman akuntansi. Kesimpulan penelitian ini menunjukkan bahwa kecerdasan logis matematis berpengaruh secara signifikan terhadap pemahaman akuntansi. Implikasinya adalah jika ingin meningkatkan pemahaman tentang akuntansi salah satu jalan yang bisa dilakukan adalah dengan meningkatkan kecerdasan logis matematis peserta didik.

\section{Hipotesis 3}

$\mathrm{F}_{\text {hitung }}(\mathrm{AB})>\mathrm{F}_{(0,05)(1 ; 36)}$ yakni $5,78>4,11$ maka $\mathrm{Ho}_{3}$ ditolak berarti ada interaksi antara model pembelajaran dengan kemampuan berpikir logis terhadap hasil belajar siswa pada materi laju reaksi.Dalam penelitian ini, ditemukan bahwa jika faktor model pembelajaran dengan menggunakan laboratorium (faktor A) dan kemampuan berpikir logis (faktor B) yang dikombinasikan, diperoleh adanya interaksi antara kedua faktor tersebut yang secara nyata berpengaruh terhadap hasil belajar siswa. Bentuk interaksi faktor model pembelajaran menggunakan laboratorium (faktor A) dan kemampuan berpikir logis (faktor B) terhadap hasil belajar siswa dapat digambarkan sebagaimana ditunjukkan pada Gambar 1.

Berdasarkan bentuk interaksi antara model pembelajaran denggan menggunakan laboratorium (faktor A) dan kemampuan berpikir logis (faktor B) terhadap hasil belajar siswa pada materi laju reaksi sebagaimana disajikan pada gambar 1 dapat disimpulkan bahwa pengajaran dengan model Inkuiri dengan menggunakan laboratorium riil dengan kemampuan berpikir logis tinggi memberikan hasil belajar siswa tertinggi. Sementara pengajaran dengan model inkuiri dengan menggunakan laboratorium riil dengan kemampuan berpikir logis tinggi memberikan hasil belajar siswa lebih tinggi, 
dengan rataan $83,77 \pm 6,07$. Selanjutnya, pengajaran dengan model Inkuiri dengan menggunakan laboratorium Riil dengan kemampuan berpikir logis rendah memberikan hasil belajar siswa yang rendah, dengan rataan $76,17 \pm 6,71$. Hasil belajar siswa yang memiliki kemampuan berpikir logis tinggi yang diberikan pengajaran dengan model inkuiri menggunakan laboratorium riil memberikan hasil belajar yang lebih tinggi dikarenakan model inkuiri mengajarkan siswa untuk berpikir lebih kreatif dalam memecahkan suatu masalah dan mandiri dibantu dengan penggunaan laboratorium Riil dibandingkan dengan siswa yang memiliki kemampuan berpikir logis tinggi yang diberikan pengajaran dengan model inkuiri menggunakan laboratorium virtual memberikan hasil belajar yang tidak lebih baik dari model inkuiri menggunakan laboratorium riil dikarenakan pada model inkuiri menggunakan laboratorium virtual, siswa tidak bergerak langsung ke dalam laboratorium, dengan kata lain hanya menggunakan animasi komputer saja. Oleh karena itu, siswa kurang kreatif, dan kurang memahami praktikum yang akan diujikan.
Sementara penerapan model Inkuiri menggunakan laboratorium riil dan penerapan model inkuiri menggunakan laboratorium virtual dengan kemampuan berpikir logis rendah sama-sama memberikan rataan hasil belajar yang sama-sama rendah.

Pada Penelitian ini, siswa yang memiliki kemampuan berpikir logis rendah dengan menggunakan laboratorium virtual mempunyai rataan hasil belajar yang lebih tinggi daripada siswa yang mempunyai kemampuan berpikir logis rendah dengan menggunakan laboratorium Riil yaitu dengan rataan $76,29 \pm 7,84$ dan $76,17 \pm 6,71$. Siswa dengan kemampuan berpikir logis rendah dapat melakukan pengamatan langsung dengan menggunakan laboratorium riil sementara dengan laboratorium virtual siswa melakukan pengamatan secara tidak langsung. Siswa yang memiliki kemampuan berpikir logis rendah selama proses pembelajaran lebih banyak memerlukan pengalaman yang secara nyata untuk dapat berpikir logis, menentukan tindakan dan menarik kesimpulan dalam proses pembelajaran.

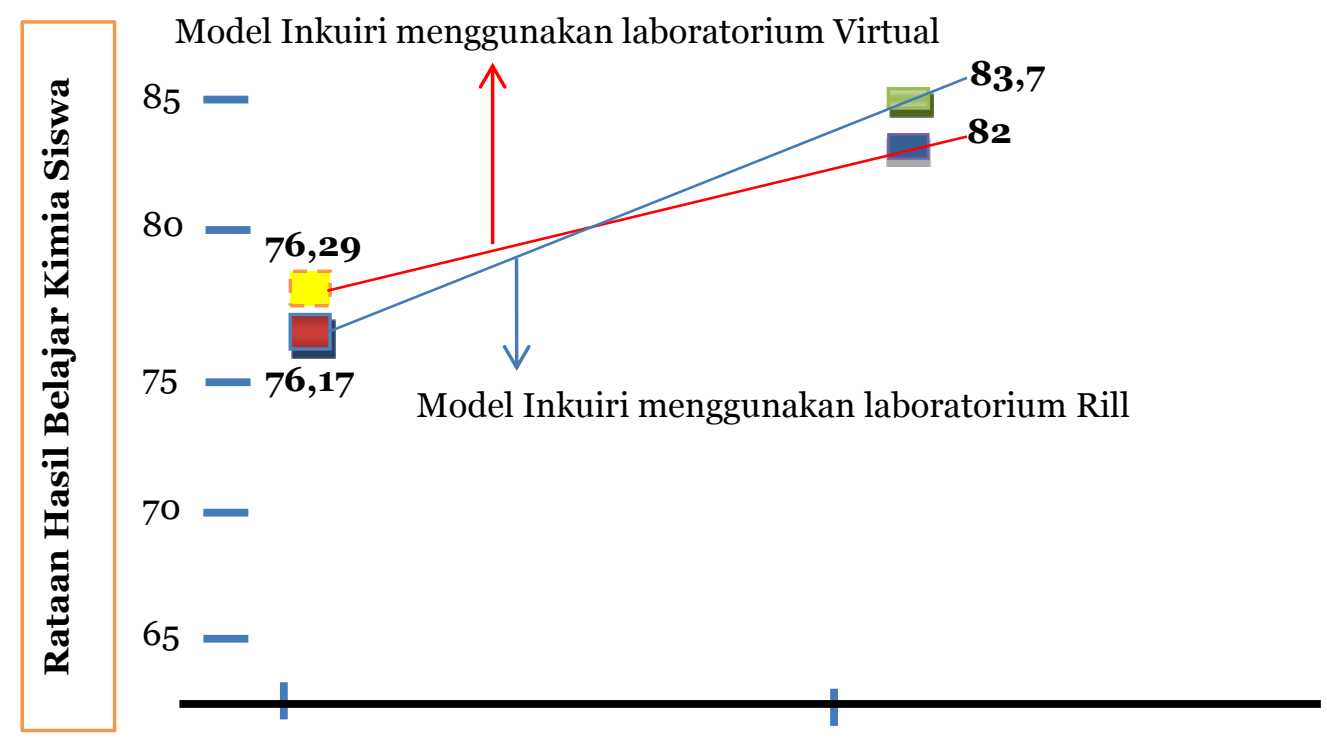

Kemampuan berpikir logis rendah Kemampuan berpikir logis tinggi

Gambar 1. Bentuk interaksi faktor model pembelajaran menggunakan laboratorium (faktor A) dan kemampuan berpikir logis (faktor B) terhadap hasil belajar siswa.

\section{KESIMPULAN}

Dari penelitian ini, maka dapat disimpulkan bahwa: (1) ada pengaruh model pembelajaran Inkuiri dengan menggunakan laboratorium riil dan laboratorium virtual terhadap hasil belajar siswa pada materi laju 
reaksi; (2) ada pengaruh kemampuan berpikir logis tinggi dan kemampuan berpikir logis rendah terhadap hasil belajar siswa pada materi laju reaksi; dan (3) ada interaksi antara model pembelajaran dengan kemampuan berpikir logis terhadap hasil belajar siswa pada materi laju reaksi.

\section{DAFTAR PUSTAKA}

Argandi, R., Martini, S., \& Saputro, C. (2013). Pembelajaran Kimia Dengan Metode Inquiry Terbimbing Dilengkapi Kegitan Laboratorium Real Dan Virtual Pada Pokok Bahasan Pemisahan Campuran. Jurnal Pendidikan Kimia (JPK), 2:44-45.

Fatturohman, M. (2015). Model-model pembelajaran Inovatif. Yogyakarta: Pustaka belajar

Gahardiana, G. (2015). Pengaruh Model Pembelajaran Berbasis Proyek (Inkuiri) Terhadap Hasil Belajar Kimia Siswa Kelas XI SMAN 1 Jonggat Pada Materi Koloid Tahun Ajaran 2014/2015. Artikel Penelitian Jurusan Pendidikan MIPA, Fakultas Keguruan dan Ilmu Pendidikan, Universitas Mataram.

Hamida, N., Mulyani, B., \& Utami, B. (2012). Studi Komparasi Penggunaan Laboratorium Virtual Dan Laboratorium Riil Dalam Pembelajaran Student Teams Achievement Division (Stad) Terhadap Prestasi Belajar Ditinjau Dari Kreativitas Siswa Pada Materi Pokok Sistem Koloid Kelas XI Semester Genap Sma Negeri 1 Banyudono Tahun Pelajaran 2011/2012. Jurnal Pendidikan Kimia (JPK), 2(2):7-15.

Legimin, (2010). Pengaruh Model Pembelajaran dan Kemampuan Berpikir Logis Terhadap
Hasil Belajar Matematika Siswa SMA Negeri 1 Kuala. Tesis, Pascasarjana, Unimed, Medan.

Nurrokhmah, I.E., \& Sunarto, W. (2013). Pengaruh Penerapan Virtual Labs Berbasis Inkuiri Terhadap Hasil Belajar Kimia. Journal Chemistry in Educati, 2(1):200-207.

Pratiwi, F.A. (2016). Pengaruh Penggunaan Model Discovery Learning Dengan Pendekatan Saintifik Terhadao Ketrampilan Berpikir Kritis Siswa SMA. Artikel Penelitian FMIPA Universitas Tanjungpura, Pontianak.

Rohmawati, A., Masyukuri, M., \& Utomo, B.S. (2016). Implementasi Pembelajaran Kimia Dengan Inkuiri Bebas Termodifikasi Bermedia Laboratorium Rill Dan Virtual Kelas XI Pada pokok Bahasan Sistem Koloid. Jurnal Pendidikan Kimia, 5(1):71-77.

Rokhimulloh. (2010). Pembelajaran Kimia Menggunakan Laboratorium Virtual dan Laboratorium Riil Melalui Metode Eksperimen Dengan Memperhatikan Emotion Spiritual Quotient (ESQ) Dan Kemampuan Awal Siswa. Tesis ,FMIPA, Universitas Sebelas Maret, Surakarta.

Suriasumantri. (2015). Sistematika Berfikir Logis Menggunakan Media Simulasi Fisika Pada Siswa Kelas X Di SMA Negeri 6 Kota Bengkulu. E-Journal Fisika.

Swandi, A., Nuru, H.S., \& Irsan. (2014). Pengembangan Media Pembelajaran Laboratorium Virtual Untuk Mengatasi Miskonsepsi Pada Materi Fisika Inti di SMAN 1 Binamu Jeneponto. Jurnal Fisika Indonesia, XVIII(52):20-24.

Trianto, (2014). Mendesaian Model Pembelajaran Inovatif, Progresif, dan kontekstual. Jakarta: Prenada Media Group. 